\title{
Early Trifecta valve failure: Report of a cluster of cases from a tertiary care referral center
}

\author{
Ankur Kalra, MD, Hasan Rehman, MD, Mahesh Ramchandani, MD, Colin M. Barker, MD, \\ Gerald M. Lawrie, MD, Ross M. Reul, MD, Michael J. Reardon, MD, and Neal S. Kleiman, MD
}

\begin{abstract}
Background: The Trifecta valve (St Jude Medical, Inc, St Paul, Minn) was approved for commercial use by the US Food and Drug Administration in 2011. Several isolated cases have been reported since then, describing early structural valve deterioration. We report a case series of 8 Trifecta valve failures, describing patients' clinical substrate and management, and the pathologic characteristics of the explanted valves.
\end{abstract}

Methods: Trifecta valve failure occurred in 7 patients ( 8 valves) receiving $19-\mathrm{mm}$ $(\mathrm{n}=2), 21-\mathrm{mm}(\mathrm{n}=3), 23-\mathrm{mm}(\mathrm{n}=1)$, and $25-\mathrm{mm}(\mathrm{n}=2)$ valves. The mean duration of valve durability was $32 \pm 21$ months, and the most common lesion was prosthetic regurgitation. The mean Society of Thoracic Surgeons risk score for perioperative mortality at the time of reintervention was $9.75 \% \pm 8.1 \%$. Heart failure exacerbation was the most common presenting symptom.

Results: Five patients underwent surgical aortic valve replacement, 2 patients received valve-in-valve transcatheter aortic valve replacement, and 1 patient died of cardiogenic shock before reintervention. The most common pathologic finding in the explanted valves was a tan-yellow fibrofatty circumferential pannus adherent to the inflow portion of the Trifecta valve.

Conclusions: Our findings provide further insights into the pathologic mechanisms leading to early Trifecta valve failure. In addition to tear of the noncoronary cusp of the Trifecta prosthesis described as the most common mechanism in the literature for its failure, circumferential pannus formation composed of fibrofatty tissue in the inflow portion and leaflet calcification concentrated around the posts in the outflow portion are important mechanisms contributing toward early Trifecta valve failure. (J Thorac Cardiovasc Surg 2017;154:1235-40)

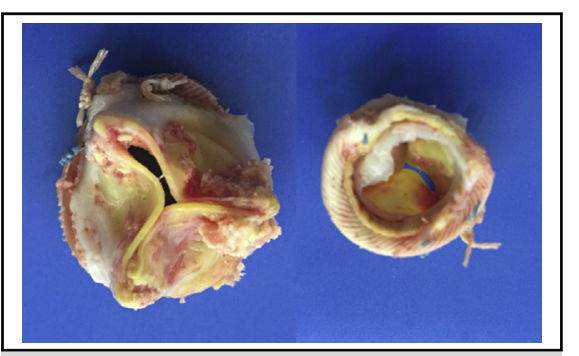

Explanted Trifecta valve with structural degeneration in inflow and outflow portions.

\section{Central Message}

The Trifecta valve design provides a theoretic advantage for a better hemodynamic profile. However, early pannus formation and leaflet calcification may contribute toward early valve failure in a "real-world" experience.

\section{Perspective}

Early pannus formation in the inflow portion resulting in a decrease in the effective orifice area and leaflet calcification concentrated around the posts in the outflow portion of the Trifecta valves causing restricted leaflet mobility or prosthetic regurgitation are important mechanisms contributing toward early Trifecta valve failure.

See Editorial Commentaries pages 1241 and 1243.
Trifecta stented bioprosthetic valves (St Jude Medical, Inc, St Paul, Minn) were approved by the US Food and Drug Administration for commercial use in 2011. ${ }^{1}$ The Trifecta valve is composed of a titanium framework covered with porcine pericardium. The valve leaflets

\footnotetext{
From the Houston Methodist DeBakey Heart and Vascular Center, Houston Methodist Hospital, Houston, Tex; and Weill Cornell Medical College, New York, NY.

A.K. and H.R. contributed equally to this work.

Received for publication Jan 23, 2017; revisions received April 13, 2017; accepted for publication May 7, 2017; available ahead of print June 10, 2017.

Address for reprints: Neal S. Kleiman, MD, 6565 Fannin St, Houston, TX 77030

(E-mail: nkleiman@ @oustonmethodist.org).

$0022-5223 / \$ 36.00$

Copyright (c) 2017 by The American Association for Thoracic Surgery

http://dx.doi.org/10.1016/j.jtcvs.2017.05.044
}

are made from bovine pericardium. Porcine and bovine tissue are preserved and cross-linked using glutaraldehyde, and the valve is sterilized with formaldehyde and ethanol. Additional processing is done with an ethanolbased anticalcification agent. The supra-annular design and external wrap of the valve leverage a theoretic advantage to facilitate deployment in subjects with smaller aortic roots. Midterm 6-year follow-up results from the

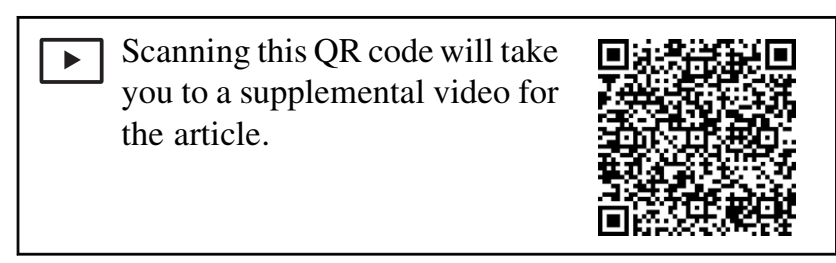


TABLE 1. Clinical characteristics of patients at the time of initial Trifecta (St Jude Medical, Inc, St Paul, Minn) valve implantation

\begin{tabular}{|c|c|c|c|c|c|c|c|c|c|}
\hline ID & Age/gender & Valve lesion & $\begin{array}{c}\text { Mean } \\
\text { gradient } \\
(\mathbf{m m} \mathbf{H g})\end{array}$ & $\begin{array}{c}\text { Peak } \\
\text { velocity } \\
(\mathbf{m} / \mathbf{s})\end{array}$ & $\begin{array}{c}\text { Ejection } \\
\text { fraction } \\
(\%)\end{array}$ & $\begin{array}{c}\text { STS score } \\
\text { (mortality) } \\
(\% / y)\end{array}$ & Pathologic findings & $\begin{array}{c}\text { Year of } \\
\text { implant }\end{array}$ & $\begin{array}{c}\text { Valve } \\
\text { size }(\mathrm{mm})\end{array}$ \\
\hline 1 & $59 \mathrm{y} /$ Female & Stenosis & - & - & - & 1.2 & - & 2011 & 19 \\
\hline 2 & $53 \mathrm{y} /$ Female & Stenosis & 38 & 4.1 & 60 & 3.7 & Myxoid change and calcification & 2014 & 21 \\
\hline 3 & $72 \mathrm{y} /$ Female & Stenosis & 34 & 4.0 & 55 & 1.8 & Calcified and fibrotic valve leaflets & 2012 & 21 \\
\hline 4 & $70 \mathrm{y} /$ Female & Stenosis & - & - & - & 1.5 & - & 2013 & 19 \\
\hline 5 & $80 \mathrm{y} /$ Female & Stenosis & 27 & - & 40 & 4.2 & Myxoid degeneration and calcification & 2013 & 23 \\
\hline 6 & $56 \mathrm{y} / \mathrm{Male}$ & Stenosis & 58 & 4.6 & 65 & 2.5 & - & 2013 & 25 \\
\hline 7 & $56 \mathrm{y} / \mathrm{Male}$ & Mixed & 13 & 2.8 & 55 & 3.4 & Intact with minimal attached soft tissue & 2014 & 25 \\
\hline 8 & $75 \mathrm{y} /$ Female & Stenosis & 33 & - & 60 & 2.1 & - & 2012 & 21 \\
\hline
\end{tabular}

STS, Society of Thoracic Surgeons.

premarket approval study in 710 eligible patients have shown that freedom from reoperation was $99.4 \%$, $98.6 \%$, and $96.0 \%$ at 1 year, 3 years, and 6 years postimplant, respectively. ${ }^{2}$ At our tertiary care referral teaching hospital, we have recently encountered a cluster of early Trifecta valve failure cases. This article discusses the clinical substrate and management of these cases and the pathologic characteristics of the explanted Trifecta valves.

\section{CASE REPORTS}

\section{Baseline Characteristics}

We encountered 11 Trifecta valve failures in $10 \mathrm{pa}-$ tients. Of these patients, 3 had prosthetic valve endocarditis and have been excluded from this case series. The final analysis includes 8 Trifecta valve failures in 7 patients. The mean age of patients at the time of presentation was $68 \pm 11$ years. Six valve failures occurred in women, and 2 failures occurred in men. Five patients were Caucasian, 1 was African American, and 1 was Hispanic. Failure of a 19-mm Trifecta valve occurred in 2 patients, failure of a $21-\mathrm{mm}$ Trifecta valve occurred in 3 patients, failure of a $23-\mathrm{mm}$ Trifecta valve occurred in 1 patient, and failure of a $25-\mathrm{mm}$ Trifecta valve occurred in 2 patients. Valve durability among these patients ranged from 3 months to 5 years, with a mean duration of $32 \pm 21$ months. Heart failure exacerbation was the most common manifestation with New York Heart Association class III symptoms. All 7 patients had underlying hypertension, and coronary atherosclerosis was present in 3 patients. Other comorbidities included asthma $(\mathrm{n}=1)$, chronic obstructive pulmonary disease $(\mathrm{n}=1)$, cirrhosis $(n=1)$, diabetes mellitus $(n=1)$, end-stage renal disease $(n=1)$, hyperlipidemia $(n=4)$, and history of tobacco use $(\mathrm{n}=3)$. Two patients had native bicuspid valves, and 2 patients had concomitant coronary artery bypass graft surgery at the time of first Trifecta valve replacement (Table 1). Five patients received antiplatelet therapy with aspirin after Trifecta valve implantation; 1 patient received anticoagulant therapy with non-vitamin $\mathrm{K}$ oral anticoagulant apixaban (for thromboembolism prophylaxis in atrial fibrillation).

\section{Echocardiographic Findings}

The mode of presentation was prosthetic valve stenosis in 2 patients ( 1 with a $19-\mathrm{mm}$ valve and 1 with a $21-\mathrm{mm}$ valve), severe aortic regurgitation in 4 patients ( 1 with a $21-\mathrm{mm}$ valve, 1 with a $23-\mathrm{mm}$ valve, and 2 with $25-\mathrm{mm}$

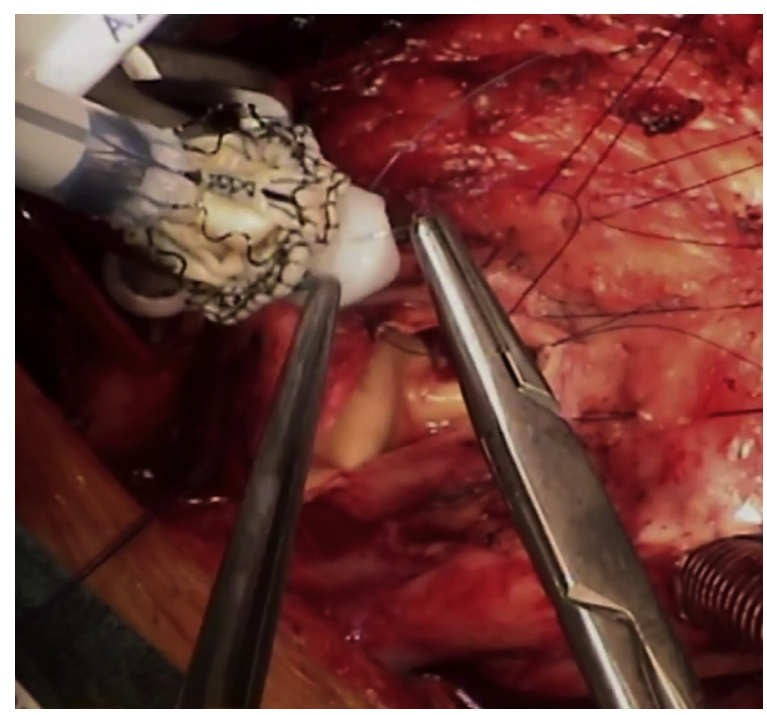

VIDEO 1. Redo surgical aortic valve replacement after early Trifecta (St Jude Medical, Inc, St Paul, Minn) valve failure. The Trifecta valve in this patient was explanted and replaced with a medium-sized Perceval valve. The video also demonstrates the degenerative findings reported in our case series. Video commentary: Dr Mahesh Ramchandani, Chief, Division of Cardiac Surgery, Methodist DeBakey Heart and Vascular Center. Video available at: http://www.jtcvsonline.org/article/S0022-5223(17) 31046-2/addons. 
TABLE 2. Clinical characteristics of patients with Trifecta valve failure at the time of reintervention

\begin{tabular}{|c|c|c|c|c|c|c|c|c|c|c|c|c|c|}
\hline ID & Age/gender & $\begin{array}{l}\text { Year of } \\
\text { implant } r\end{array}$ & $\begin{array}{l}\text { Year of I } \\
\text { eplacement }\end{array}$ & $\begin{array}{c}\text { Durability } \\
\text { (mo) }\end{array}$ & $\begin{array}{l}\text { Valve } \\
\text { size } \\
(\mathbf{m m})\end{array}$ & $\begin{array}{l}\text { Valve } \\
\text { lesion }\end{array}$ & $\begin{array}{c}\text { Mean } \\
\text { gradient } \\
(\mathrm{mm} \mathrm{Hg})\end{array}$ & $\begin{array}{c}\text { Peak } \\
\text { velocity } \\
(\mathrm{m} / \mathbf{s})\end{array}$ & $\begin{array}{l}\text { Ejection } \\
y \text { fraction } \\
(\%)\end{array}$ & $\begin{array}{c}\text { Mode (type) } \\
\text { of valve } \\
\text { replacement (size) }\end{array}$ & $\begin{array}{c}\text { STS score } \\
(\text { mortality) } \\
(\% / y)\end{array}$ & $\begin{array}{c}\text { Pathologic } \\
\text { findings }\end{array}$ & Outcome \\
\hline 1 & $65 \mathrm{y} /$ Female* & 2011 & 2016 & 60 & 19 & Stenosis & 73 & 5.2 & 65 & $\begin{array}{l}\text { SAVR (Perceval, } \\
\text { Sorin, Saluggia, } \\
\text { Italy) } \\
\text { (Small) }\end{array}$ & 4.2 & $\begin{array}{l}\text { Multiple } \\
\text { calcifications } \\
\text { on valve } \\
\text { leaflets }\end{array}$ & $\begin{array}{l}\text { Died on POD } \\
24 \text { of } \\
\text { respiratory } \\
\text { failure }\end{array}$ \\
\hline 2 & $55 \mathrm{y} /$ Female $\dagger, \ddagger$ & 2014 & 2016 & 24 & 21 & Stenosis & 71 & 5.1 & 60 & $\begin{array}{l}\text { TAVR (CoreValve } \\
\text { Evolut R; } \\
\text { Medtronic, Inc, } \\
\text { Minneapolis, } \\
\text { Minn) } \\
(23 \mathrm{~mm})\end{array}$ & 12.1 & - & $\begin{array}{l}\text { Doing well } 5 \text { mo } \\
\text { postoperatively }\end{array}$ \\
\hline 3 & $75 \mathrm{y} /$ Female $^{*}, \ddagger$ & 2012 & 2016 & 48 & 21 & Regurgitation & 23 & 3.3 & 55 & $\begin{array}{l}\text { SAVR (Trifecta) } \\
\quad(21 \mathrm{~mm})\end{array}$ & 9.3 & $\begin{array}{l}\text { Tan-yellow } \\
\text { fibrofatty } \\
\text { tissue } \\
\text { attached } \\
\text { to the inflow } \\
\text { portion of the } \\
\text { valve }\end{array}$ & $\begin{array}{l}\text { Doing well } 8 \text { mo } \\
\text { postoperatively } \\
\text { e }\end{array}$ \\
\hline 4 & $74 \mathrm{y} /$ Female* & 2013 & 2016 & 36 & 19 & Mixed & 10 & 2.1 & 60 & $\begin{array}{l}\text { SAVR } \\
\quad \text { (Perceval) } \\
\text { (Medium) }\end{array}$ & 9.3 & $\begin{array}{l}\text { Circumferential } \\
\text { pannus } \\
\text { adherent } \\
\text { to the inflow } \\
\text { portion of the } \\
\text { valve }\end{array}$ & $\begin{array}{l}\text { Doing well } 6 \text { mo } \\
\text { postoperatively }\end{array}$ \\
\hline 5 & $83 \mathrm{y} /$ Female $^{*}, \ddagger, \S$ & & 2016 & 36 & 23 & Regurgitation & 8 & 1.9 & 55 & $\begin{array}{l}\text { TAVR (CoreValve } \\
\text { Evolut R) } \\
(26 \mathrm{~mm})\end{array}$ & 7.9 & - & $\begin{array}{l}\text { Doing well } 6 \text { mo } \\
\text { postoperatively }\end{array}$ \\
\hline 6 & $57 \mathrm{y} / \mathrm{Male} *$ & & 2014 & 4 & 25 & Regurgitation & - & - & 80 & $\begin{array}{l}\text { SAVR (Trifecta) } \\
\quad(25 \mathrm{~mm})\end{array}$ & 3.4 & $\begin{array}{l}\text { Friable tissue } \\
\text { along left } \\
\text { cusp }\end{array}$ & $\begin{array}{l}\text { Underwent repeat } \\
\text { valve } \\
\text { replacement } \\
\text { in } 3 \text { mo }\end{array}$ \\
\hline 7 & 57 y/Male* & & 2014 & 3 & 25 & Regurgitation & 11 & 2.4 & 55 & $\begin{array}{l}\text { SAVR (St Jude } \\
\text { Mechanical) } \\
(29 \mathrm{~mm})\end{array}$ & - & - & $\begin{array}{l}\text { Intraoperative death } \\
\text { within } 1 \text { y while } \\
\text { repairing aortic } \\
\text { aneurysm }\end{array}$ \\
\hline 8 & 75 y/Female $*,+, \|$ & & - & 4 & 21 & Mixed & 56 & 4.8 & 45 & - & 28.1 & - & $\begin{array}{l}\text { Admitted for } \\
\text { severe AS; } \\
\text { died of } \\
\text { cardiogenic } \\
\text { shock }\end{array}$ \\
\hline
\end{tabular}

STS, Society of Thoracic Surgeons; SAVR, surgical aortic valve replacement; $P O D$, postoperative day; $A S$, aortic stenosis; TAVR, transcatheter aortic valve replacement. *Discharged on aspirin. †End-stage renal disease. ‡Initial Trifecta valve implant at our tertiary care referral center. §Discharged on anticoagulant. \|Deceased.

valves), and mixed prosthetic valve disease in 2 patients $(1$ with a $19-\mathrm{mm}$ valve and 1 with a $21-\mathrm{mm}$ valve). The interval mean increase in the mean transaortic gradient in patients with prosthetic aortic stenosis from the first echocardiogram after Trifecta valve implantation to reintervention was $23 \pm 24 \mathrm{~mm} \mathrm{Hg}$. Left ventricular systolic function was normal in all but 1 patient at the time of clinical presentation (Table 1).

\section{Management}

The mean Society of Thoracic Surgeons risk score for perioperative mortality at the time of reintervention was $9.7 \% \pm 8.1 \%$. Five valve failures underwent redo surgical aortic valve replacement with a medium-sized Perceval (Sorin, Saluggia, Italy) sutureless aortic valve $(n=2)$ (Video 1), a 21-mm Trifecta valve $(\mathrm{n}=1)$, a $25-\mathrm{mm}$ Trifecta valve $(\mathrm{n}=1)$, and a $29-\mathrm{mm}$ St Jude mechanical valve $(\mathrm{n}=1)$. Two patients had a valve-in-valve transcatheter aortic valve replacement with a $23-\mathrm{mm}$ and a 26-mm CoreValve Evolut R (Medtronic, Inc, Minneapolis, Minn). One patient died of cardiogenic shock before reintervention (Table 2).

\section{Pathologic Findings}

The predominant pathologic findings from the explanted valves were (1) the presence of a circumferential, 

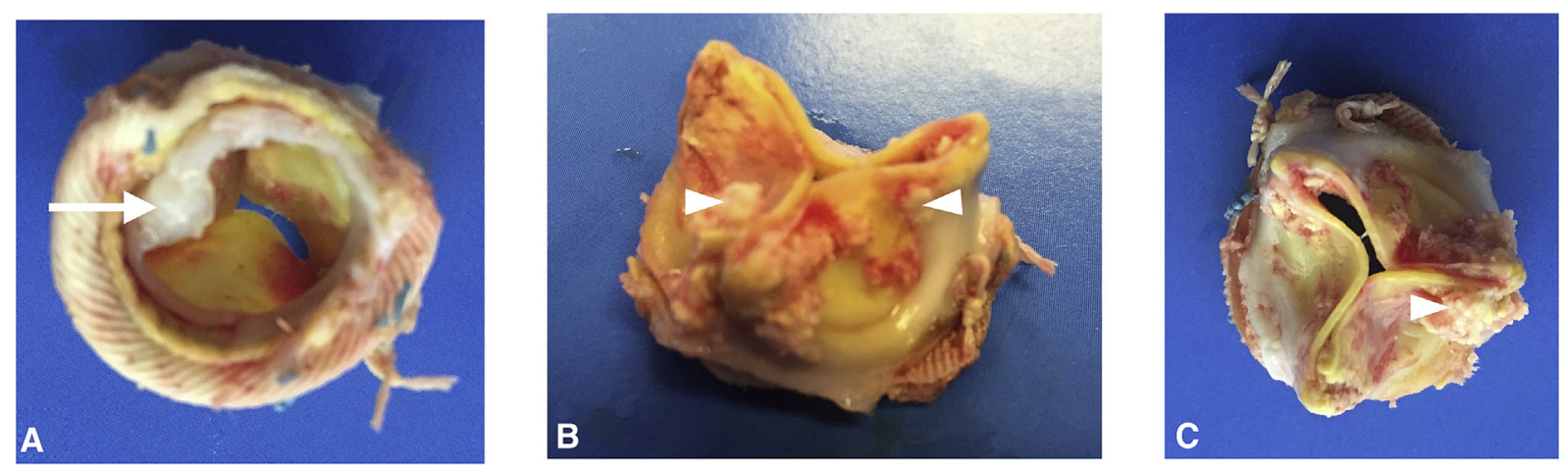

Total Number of Trifecta ${ }^{\top m}$ Valves Implanted by Size

Valve Size Distribution of Failed Trifecta $^{\mathrm{TM}}$ Valves
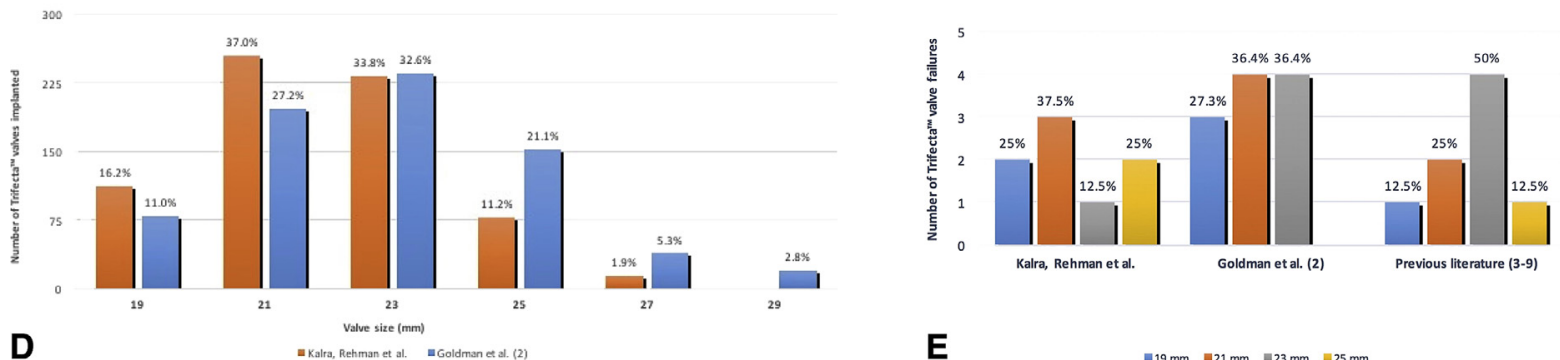

E

FIGURE 1. An explanted Trifecta valve (St Jude Medical, Inc, St Paul, Minn) demonstrating a circumferential, homogeneous, tan-yellow, fibrofatty membrane adherent to its inflow portion (arrow, A) and leaflet calcification concentrated around the posts in its outflow portion (arrowheads, B and C), leading to restricted leaflet mobility manifesting as prosthetic aortic stenosis or regurgitation. D, Histograms comparing the total number of valves (differentiated by size of implant) implanted in patients at our tertiary care referral hospital (from June 2011 to November 2016) with the number reported in the observational study by Goldman and colleagues. ${ }^{2} \mathrm{E}$, Histograms comparing valve sizes of Trifecta valve failures among isolated cases reported in the literature, ${ }^{3-9}$ cases of structural valve degeneration reported in the multicenter observational study by Goldman and colleagues, ${ }^{2}$ and our cluster of cases.

homogenous, tan-yellow, fibrofatty tissue adherent to the inflow portion of the Trifecta valve (Figure 1, A) and (2) leaflet calcification concentrated around the posts in the outflow portion of the Trifecta valve (Figure 1, B, and $C$ ). These findings were present in early structural valve deterioration manifesting as prosthetic stenosis, regurgitation, or mixed valve disease (Table 2).

\section{DISCUSSION}

We report a cluster of early Trifecta valve failure cases encountered at our tertiary care referral teaching hospital. Five failures occurred in 19- and 21-mm valves, and 3 failures occurred in 23- and $25-\mathrm{mm}$ valves. All 8 cases presented with symptoms of heart failure exacerbation with New York Heart Association class III symptoms. All valves were implanted in a supra-annular fashion using interrupted pledgeted sutures on the inflow aspect of the annulus. None of the cases of Trifecta valve implantation were performed using a continuous suturing technique. Only 1 of the 7 patients reported in this case series had end-stage renal disease.

The predominant echocardiographic lesion was prosthetic valve regurgitation, and the majority of cases were treated with repeat surgical aortic valve replacement. The hallmark pathologic findings in all of the explanted valves were the presence of a circumferential, homogeneous, tan-yellow, fibrofatty membrane adherent to the inflow portion of the Trifecta valves (Figure 1, A) and leaflet calcification concentrated around the posts in the outflow portion of the Trifecta valves (Figure 1, B, and $C$ ), leading to restricted leaflet mobility manifesting as prosthetic aortic stenosis or regurgitation. In the recently published midterm 6-year outcomes of the 710 Trifecta valves that were implanted in patients between 2007 and 2009 during the premarket approval phase, 18 valves were explanted. ${ }^{2}$ Of these 18 valves, 11 were explanted because of structural valve degeneration due to calcification or fibrous thickening $(\mathrm{n}=10)$ or noncalcified leaflet tear $(n=1){ }^{2}$ The majority of cases of structural valve deterioration in the premarket approval phase study occurred in the $23-\mathrm{mm}$ and $25-\mathrm{mm}$ Trifecta valves, in contrast to the current series in which most failures occurred with smaller valve sizes. ${ }^{2}$ In the isolated cases of early Trifecta valve failure reported in the literature $(\mathrm{n}=8)$, the most common lesion causing prosthetic dysfunction was aortic regurgitation due to leaflet tear 
TABLE 3. Trifecta valve failure cases reported in the literature

\begin{tabular}{|c|c|c|c|c|c|c|c|c|}
\hline Author & $\begin{array}{c}\text { Year of } \\
\text { publication }\end{array}$ & Age/gender & $\begin{array}{c}\text { Valve } \\
\text { size }(\mathbf{m m})\end{array}$ & Valve lesion & $\begin{array}{c}\text { Mean } \\
\text { gradient } \\
(\mathbf{m m ~ H g})\end{array}$ & $\begin{array}{l}\text { Durability } \\
\text { (mo) }\end{array}$ & $\begin{array}{l}\text { Mode (type) of valve } \\
\text { replacement (size) }\end{array}$ & Surgical findings \\
\hline $\begin{array}{l}\text { Piñón and } \\
\text { colleagues }^{3}\end{array}$ & 2014 & $71 \mathrm{y} /$ Female & 21 & Regurgitation & - & 34 & $\begin{array}{l}\text { SAVR (St Jude Epic) } \\
(21 \mathrm{~mm})\end{array}$ & $\begin{array}{l}\text { Parastent tear in the } \\
\text { noncoronary cusp }\end{array}$ \\
\hline $\begin{array}{l}\text { Saxena and } \\
\text { colleagues }\end{array}$ & 2014 & $67 \mathrm{y} /$ Female & 21 & Mixed & 75 & 48 & $\begin{array}{l}\text { SAVR (Carbomedics Top } \\
\text { Hat, Sulzer, Carbomedics, } \\
\text { Austin, Tex }) \\
(21 \mathrm{~mm})\end{array}$ & $\begin{array}{c}\text { Structural valve } \\
\text { degeneration }\end{array}$ \\
\hline $\begin{array}{l}\text { Campisi and } \\
\text { colleagues }^{5}\end{array}$ & 2014 & $78 \mathrm{y} /$ Female & 19 & Regurgitation & - & 3 & $\begin{array}{l}\text { SAVR (Carpentier-Edwards } \\
\text { PERIMOUNT Magna } \\
\text { Ease; Edwards } \\
\text { Lifesciences, Irvine, Calif) } \\
(19 \mathrm{~mm})\end{array}$ & $\begin{array}{l}\text { Noncoronary leaflet } \\
\text { restriction leading to } \\
\text { incomplete coaptation }\end{array}$ \\
\hline $\begin{array}{l}\text { Campisi and } \\
\text { colleagues }^{5}\end{array}$ & 2014 & 74 y/Male & 23 & Stenosis & 52 & 9 & $\begin{array}{l}\text { SAVR (Carpentier-Edwards } \\
\text { PERIMOUNT Magna } \\
\text { Ease) } \\
(23 \mathrm{~mm})\end{array}$ & Partial stent tear \\
\hline $\begin{array}{l}\text { Haussig and } \\
\text { colleagues }^{6}\end{array}$ & 2014 & $70 \mathrm{y} / \mathrm{Male}$ & 23 & Regurgitation & - & 36 & $\begin{array}{l}\text { TAVR (CoreValve Evolut R) } \\
(23 \mathrm{~mm})\end{array}$ & - \\
\hline $\begin{array}{c}\text { Jochheim and } \\
\text { colleagues }^{7}\end{array}$ & 2015 & $53 \mathrm{y} / \mathrm{Male}$ & 25 & Stenosis & 45 & 60 & $\begin{array}{l}\text { TAVR (Lotus; Boston } \\
\text { Scientific Corp, } \\
\text { Marlborough, Mass) } \\
(23 \mathrm{~mm})\end{array}$ & - \\
\hline $\begin{array}{l}\text { Kim and } \\
\text { colleagues }^{8}\end{array}$ & 2015 & 74 y/Male & 23 & Regurgitation & - & 36 & $\begin{array}{l}\text { TAVR (Portico, St Jude } \\
\text { Medical) } \\
(23 \mathrm{~mm})\end{array}$ & - \\
\hline $\begin{array}{l}\text { Yoshida and } \\
\text { colleagues }\end{array}$ & 2016 & $83 \mathrm{y} / \mathrm{Male}$ & 23 & Regurgitation & - & 19 & $\begin{array}{l}\text { SAVR (Carpentier-Edwards } \\
\text { PERIMOUNT Magna Ease) }\end{array}$ & $\begin{array}{l}\text { Leaflet tear between } \\
\text { noncoronary and right } \\
\text { coronary cusps }\end{array}$ \\
\hline
\end{tabular}

SAVR, Surgical aortic valve replacement; TAVR, transcatheter aortic valve replacement

involving the noncoronary cusp (Table 3). ${ }^{3-9}$ Most cases also involved Trifecta valves of $23-\mathrm{mm}$ and $25-\mathrm{mm}$ sizes (Table 3 and Figure 1, D). - $^{5-9}$

The design of the Trifecta valve provides a theoretic advantage for a better hemodynamic profile because the valve leaflets are externally mounted on a thin flexible titanium stent with no alignment stitch used on top of the leaflets, a design characteristic that has been implicated as the plausible cause for early valve failure in earlier iterations of pericardial tissue valves. ${ }^{10}$ The most common cause of structural valve deterioration in the premarket approval phase study was fibrous thickening or calcific leaflet degeneration. ${ }^{2}$ In the cluster of cases that we have reported, the most common cause of early valve failure was excessive pannus formation in the inflow portion, plausibly due to an inflammatory reaction to the porcine pericardium covering the framework and leaflet calcification concentrated around the posts in the outflow portion of the Trifecta valve, inhibiting leaflet mobility leading to prosthetic aortic stenosis or regurgitation. Pannus formation may contribute to leaflet mobility restriction per se or incite a biological reaction progressing to leaflet thrombosis, eventually causing leaflet degeneration in the form of fibrosis or calcification. ${ }^{11}$

Most cases of Trifecta valve failure in the literature, similar to our experience, were managed by repeat surgical aortic valve replacement. However, valve-in-valve transcatheter aortic valve replacement is a feasible approach that can be deployed in managing this patient subset, although long-term efficacy data with regard to this approach are currently lacking. ${ }^{6-8}$

Although early degeneration in our case series may be due to the manufacturing defect tracked to a specific lot number, random serial number distribution across different valve sizes (serial numbers in chronologic order: \#13812037 [21 $\mathrm{mm}]$; \#13912680 [21 $\mathrm{mm}]$; $\left.\begin{array}{lll}\# 14133719 & {[23} & \mathrm{mm}\end{array}\right] ; \quad \# 14386447 \quad\left[\begin{array}{ll}21 & \mathrm{~mm}\end{array}\right] ;$ $\# 180040492$ [25 mm]; and \#180087270 [25 mm]), in addition to the 2 early Trifecta valve failure cases that were initially operated at outside centers, makes it less likely. 


\section{CONCLUSIONS}

The midterm 6-year follow-up results from the premarket approval phase study on 710 patients has demonstrated a $96.0 \%$ reoperation-free rate after Trifecta valve replacement. ${ }^{2}$ We have encountered a cluster of early Trifecta valve failure cases in a "real-world" experience in a highvolume (692 Trifecta valve implants from June 2011 to November 2016) tertiary care referral teaching hospital. The most common cause of early valve failure in these cases was excessive pannus formation in the inflow portion of the Trifecta valve. More studies documenting "real-world" long-term follow-up of Trifecta valves are required to establish their durability and long-term efficacy.

\section{Conflict of Interest Statement}

Authors have nothing to disclose with regard to commercial support.

\section{References}

1. Food and Drug Administration. St Jude Medical Trifecta Valve-P100029. Available at: http://www.fda.gov/MedicalDevices/ProductsandMedicalProcedures/ DeviceApprovalsandClearances/Recently-ApprovedDevices/ucm254501.htm. Accessed November 25, 2016

2. Goldman S, Cheung A, Bavaria JE, Petracek MR, Groh MA, Schaff HV. Midterm multi-center clinical and hemodynamic results for the Trifecta aortic pericardial valve. J Thorac Cardiovasc Surg. 2017;153:561-9.e2.
3. Piñón M, Durán D, Pazos P, Pradas G. Leaflet tear in a Trifecta aortic bioprosthesis 34 months after implantation. Interact Cardiovasc Thorac Surg. 2015;20:281-2.

4. Saxena P, Greason KL, Schaff HV. Early structural valve deterioration of the Trifecta aortic valve biological prosthesis: a word of caution. J Thorac Cardiovasc Surg. 2014;147:e10-1.

5. Campisi S, Camilleri L, Innorta A, Azarnoush K. Early failures of Trifecta aortic bioprosthesis. J Thorac Cardiovasc Surg. 2014;148:e133-4.

6. Haussig S, Schuler G, Linke A. Treatment of a failing St Jude Medical Trifecta by Medtronic Corevalve Evolut valve-in-valve implantation. JACC Cardiovasc Interv. 2014;7:e81-2.

7. Jochheim D, Theiss H, Bauer A, Massberg S, Mehilli J. First implantation of repositionable Lotus valve in a degenerated Trifecta bioprosthesis. J Interv Cardiol. 2015;28:264-5.

8. Kim WK, Kempfert J, Walther T, Möllmann H. Transfemoral valve-in-valve implantation of a St Jude Medical Portico in a failing trifecta bioprosthesis: a case report. Clin Res Cardiol. 2015;104:363-5.

9. Yoshida K, Fukunaga N, Sakon Y, Koyama T. Early failure of Trifecta bioprosthesis in the aortic position. J Card Surg. 2016;31:526.

10. Singhal P, Luk A, Butany J. Bioprosthetic heart valves: impact of implantation on biomaterials. ISRN Biomaterials. 2013;2013: Article ID 728791, 14 pages.

11. Egbe AC, Pislaru SV, Pellikka PA, Poterucha JT, Schaff HV, Maleszewski JJ, et al. Bioprosthetic valve thrombosis versus structural failure: clinical and echocardiographic predictors. J Am Coll Cardiol. 2015;66: 2285-94.

Key Words: aortic stenosis, bioprosthetic, prosthetic valve, structural valve deterioration, trifecta 